\title{
Gastrointestinal pathology of autologous graft-versus-host disease following hematopoietic stem cell transplantation: a clinicopathological study of 17 cases
}

\author{
Christopher H Cogbill ${ }^{1}$, William R Drobyski ${ }^{2}$ and Richard A Komorowski ${ }^{1}$ \\ ${ }^{1}$ Department of Pathology, Medical College of Wisconsin, Milwaukee, WI, USA and ${ }^{2}$ Bone Marrow Transplant \\ Program, Department of Medicine, Medical College of Wisconsin, Milwaukee, WI, USA
}

\begin{abstract}
Graft-versus-host disease is the major complication after allogeneic hematopoietic stem cell transplantation and is attributable to donor T-cell recognition of recipient alloantigens. In patients undergoing autologous hematopoietic stem cell transplantation in which there is no genetic disparity to induce an alloresponse, a syndrome similar to allogeneic graft-versus-host disease has been described. Designated as autologous graft-versus-host disease, it typically involves the skin and has reportedly caused little morbidity in this patient population. Recent data, however, suggest that autologous graft-versus-host disease can cause significant disease in the gastrointestinal tract, but its pathological spectrum of abnormalities and disease incidence are not well established. We report the development of autologous graft-versus-host disease following hematopoietic stem cell transplantation in 17 patients (15 with multiple myeloma) based on 388 autologous stem cell transplants carried out at our institution over a 6 -year period. This represents a total incidence rate of $4 \%$ and among those transplanted for multiple myeloma, $6 \%$. In all, 16 of the 17 patients had colonic biopsies performed for the diagnostic evaluation of persistent diarrhea. Biopsies in all 16 patients showed pathological evidence for graft-versus-host disease and were graded using standard grading criteria established for allogeneic graft-versus-host disease. Grades ranged from mild (grade 1/4) to severe (grade 4/4). Changes secondary to medication or infection were excluded. Responses to steroid and immunosuppressive therapy were variable but improved with continuing institutional experience. Outcomes ranged from a prompt, complete resolution of symptoms to death. Patients treated with autologous hematopoietic stem cell transplantation, particularly those with multiple myeloma, may develop a potentially life-threatening syndrome pathologically identical to allogeneic graft-versus-host disease. This diagnosis must be considered when interpreting biopsies from patients with gastrointestinal symptoms following autologous hematopoietic stem cell transplantation. Modern Pathology (2011) 24, 117-125; doi:10.1038/modpathol.2010.163; published online 15 October 2010
\end{abstract}

Keywords: autologous graft-versus-host disease; gastrointestinal graft-versus-host disease; hematopoietic stem cell transplantation

Graft-versus-host disease is a well-described complication following allogeneic hematopoietic stem cell transplantation. The gastrointestinal tract is commonly affected and histopathological criteria for establishing the diagnosis and severity are widely used. ${ }^{1,2}$ Importantly, the subtle morphological

Correspondence: Dr RA Komorowski, MD, Department of Pathology, Medical College of Wisconsin, 9200 W Wisconsin Avenue, Milwaukee, WI 53226, USA.

E-mail: rkomorow@mcw.edu

Received 3 May 2010; revised 17 July 2010; accepted 20 July 2010; published online 15 October 2010 alterations found in graft-versus-host disease that are used for its classification may be induced by infection and/or drug effects; collaboration with clinicians is a necessity.

The pathogenesis of allogeneic graft-versus-host disease is attributable to cell injury induced by conditioning regimens before hematopoietic stem cell transplantation. Antigen presentation by dendritic cells of the recipient in response to injury activates donor T-cell lymphocytes, which in concert with cytokine release and stimulation of the innate immune system, results in graft-versus-host 
disease target organ damage. ${ }^{3}$ Comprehensive reviews have been written on the pathogenesis of allogeneic graft-versus-host disease ${ }^{4-8}$ This process relies upon HLA disparity between donor and recipient to induce an alloresponse. However, in patients undergoing autologous hematopoietic stem cell transplantation in which there is no genetic disparity between infused stem cells and recipient cells, a syndrome similar to allogeneic graft-versushost disease has been described: autologous graftversus-host disease.$^{6,8}$ It typically involves the skin and, until recently, has been reported to cause little morbidity and mortality.

Recent reports have shown that autologous graftversus-host disease of the gastrointestinal tract can indeed cause significant morbidity and mortality, but the histopathological spectrum and incidence of this entity have been incompletely examined. ${ }^{9-11}$ Severe autologous graft-versus-host disease has also been identified in syngeneic (identical twin) bone marrow transplant recipients. ${ }^{12-14}$ Recognition of this process and differentiating it from other disease processes such as infection and/or drug effect would have important consequences affecting the therapy and management for such critically ill patients.

In this study, we retrospectively reviewed 17 cases of gastrointestinal graft-versus-host disease in colonic biopsies following autologous hematopoietic stem cell transplantation for multiple myeloma and non-Hodgkin's lymphoma. The goals of our study were to:

1. Examine the histopathological features of intestinal graft-versus-host disease following autologous hematopoietic stem cell transplantation and determine its spectrum of morphology and severity using criteria for intestinal graft-versus-host disease following allogeneic hematopoietic stem cell transplantation.

2. Elaborate on the incidence of autologous graftversus-host disease in the population of patients undergoing autologous hematopoietic stem cell transplantation to determine the relevance of considering the entity in the interpretation of intestinal biopsies for diarrhea.

\section{Materials and methods}

In total, 17 patients who had clinical and pathological evidence of graft-versus-host disease were identified from a population of 388 consecutive patients who underwent autologous hematopoietic stem cell transplantation for varied neoplastic conditions between January 2004 and November 2009. The clinical and pathological findings represented a novel syndrome of complications that our clinicians encountered in patients following autologous transplant. As the etiology in these cases was not always clear, our clinicians lowered the threshold for obtaining gastrointestinal biopsies to confirm a diagnosis. The first five cases in this sequence (patients 1-5) have been previously reported. ${ }^{9}$ Patients with myeloma underwent standard conditioning with melphalan following mobilization with granulocyte colony-stimulating factor with or without cyclophosphamide. Patients 8 and 17 underwent conditioning with R-BEAM (rituximab, carmustine, etoposide, cytarabine, and melphalan) and Cy/VP/TBI (cyclophosphamide, etoposide, and total body irradiation) for their lymphomas, respectively. Any transfused blood products had received $2500 \mathrm{rad}$ of irradiation to prevent potential transfusion-associated graft-versus-host disease.

In all, 16 of the 17 patients had colonic biopsies performed for the diagnostic evaluation of persistent diarrhea, which was similar to the volume and nature seen with allogeneic stem cell recipients and often in conjunction with a concurrent engraftment syndrome. Earlier patients in the series also had biopsies from small intestine and skin, driven by symptoms and findings from these anatomical sites. Medical records were reviewed to obtain additional clinical features and disease characteristics. Active medication lists at the onset of symptomatology were reviewed, excluding medications as causes of gastrointestinal pathology. Specifically, no patients were treated with drugs known to cause graft-versushost disease-like pathology, such as mycophenolate formulations, ${ }^{15}$ non-steroidal anti-inflammatory drugs, ${ }^{16}$ or laxatives. ${ }^{17}$ Clinical, laboratory, and pathological investigations for infectious agents were performed in all cases, including stool toxin assays for Clostridium difficile.

Biopsy specimens were studied by two pathologists and were graded using the following criteria on hematoxylin and eosin-stained sections, based on the following commonly used modifications of the grading systems described by Lerner et $a l^{2}$ and Sale et $a l:{ }^{1}$

grade 1 = isolated apoptotic epithelial cells, without crypt loss

grade $2=$ individual crypt loss

grade $3=$ contiguous area of multiple crypt loss

grade $4=$ extensive crypt dropout with denudation of epithelium.

Histopathological findings not commonly described in graft-versus-host disease were also recorded.

Immunoperoxidase stains were performed on all biopsies using antibodies to cytomegalovirus (1:50 or 1:75 dilutions, Dako, clones CCH2 + DDG9, Carpinteria, CA, USA) and were retrospectively reviewed. Appropriate positive and negative controls were also confirmed. No patients had histories of inflammatory bowel disease or chronic gastrointestinal illness before their hematological diagnosis. None were lost to follow-up.

\section{Results}

Clinical and pathological data are summarized in chronological sequence in Table 1. 
Table 1 Patient characteristics, pathological grading, and clinical features

\begin{tabular}{|c|c|c|c|c|c|c|c|c|c|c|c|}
\hline Patient & $\begin{array}{c}\text { Age } \\
\text { (years) }\end{array}$ & Sex & Diagnosis & $\begin{array}{l}\text { Year of } \\
\text { transplant }\end{array}$ & Engraftment $t^{\mathrm{a}}$ & $\begin{array}{l}\text { Organ } \\
\text { involvement }\end{array}$ & $\begin{array}{l}\text { Colon } \\
\text { biopsy }^{\mathrm{b}}\end{array}$ & $\begin{array}{l}\text { GVHD } \\
\text { grade }\end{array}$ & Treatment & $\begin{array}{l}\text { Response } \\
\text { to therapy }\end{array}$ & Outcome \\
\hline 1 & 47 & $\mathrm{M}$ & $\begin{array}{l}\text { MM-IgG } \\
\text { kappa }\end{array}$ & $2004^{\mathrm{d}}$ & N/A & Liver, skin & +195 & 1 & $\begin{array}{l}\text { Steroids, etanercept, } \\
\text { daclizumab, alemtuzumab }\end{array}$ & PR & $\begin{array}{l}\text { Died, day } 988, \\
\text { sepsis }\end{array}$ \\
\hline 2 & 49 & M & $\begin{array}{l}\text { MM-faint } \\
\text { kappa }\end{array}$ & $2005^{\mathrm{d}}$ & +14 & $\begin{array}{l}\text { Colon, small } \\
\text { intestine, skin }\end{array}$ & +26 & 4 & $\begin{array}{l}\text { Steroids, etanercept, } \\
\text { octreotide, budesonide }\end{array}$ & PR & $\begin{array}{l}\text { Died, day 160, } \\
\text { sepsis }\end{array}$ \\
\hline 3 & 50 & M & $\begin{array}{l}\text { MM-IgG } \\
\text { lambda }\end{array}$ & 2005 & +14 & Colon & +41 & 2 & $\begin{array}{l}\text { Steroids, alemtuzumab, } \\
\text { budesonide }\end{array}$ & NR & $\begin{array}{l}\text { Died, day } 172 \text {, } \\
\text { CNS hemorrhage }\end{array}$ \\
\hline 4 & 54 & M & $\begin{array}{l}\text { MM-IgA } \\
\text { kappa }\end{array}$ & $2007^{\mathrm{d}}$ & +10 & $\begin{array}{l}\text { Colon, small } \\
\text { intestine, skin }\end{array}$ & +13 & 4 & $\begin{array}{l}\text { Steroids, budesonide, } \\
\text { alemtuzumab }\end{array}$ & PR & $\begin{array}{l}\text { Died, day } 103 \text {, } \\
\text { relapse }\end{array}$ \\
\hline 5 & 70 & M & $\begin{array}{l}\text { MM-IgG } \\
\text { kappa }\end{array}$ & 2007 & +14 & Colon & +25 & 3 & $\begin{array}{l}\text { Steroids, alemtuzumab, } \\
\text { infliximab }\end{array}$ & PR & $\begin{array}{l}\text { Died, day } 158, \\
\text { sepsis }\end{array}$ \\
\hline 6 & 62 & $\mathrm{~F}$ & $\begin{array}{l}\text { MM-IgG } \\
\text { kappa }\end{array}$ & 2007 & +14 & $\begin{array}{l}\text { Colon, } \\
\text { duodenum }\end{array}$ & +14 & 3 & Steroids, alemtuzumab & $\begin{array}{l}\mathrm{CR} \text { at } \\
6 \text { days }\end{array}$ & alive, day 885 \\
\hline 7 & 51 & $\mathrm{~F}$ & $\begin{array}{l}\text { MM- IgG } \\
\text { kappa }\end{array}$ & 2007 & +12 & Colon & +14 & 2 & Steroids, alemtuzumab & $\mathrm{PR}$ & $\begin{array}{l}\text { Died, day } 403 \text {, } \\
\text { relapse }\end{array}$ \\
\hline 8 & 30 & $\mathrm{~F}$ & $\begin{array}{l}\text { Mediastinal } \\
\text { DLBCL }\end{array}$ & 2008 & +9 & Colon & +15 & 2 & Steroids & $\begin{array}{l}\mathrm{CR} \text { at } \\
2 \text { days }\end{array}$ & Alive, day 495 \\
\hline 9 & 58 & M & $\begin{array}{l}\text { MM-IgG } \\
\text { lambda }\end{array}$ & 2008 & +12 & $\begin{array}{l}\text { Colon, } \\
\text { duodenum }\end{array}$ & +16 & 1 & Steroids & $\begin{array}{l}\mathrm{CR} \text { at } \\
2 \text { days }\end{array}$ & Alive, day 441 \\
\hline 10 & 64 & M & $\begin{array}{l}\text { MM-IgG } \\
\text { kappa }\end{array}$ & 2008 & +10 & Colon & +14 & 2 & Steroids & $\begin{array}{l}\mathrm{CR} \text { at } \\
4 \text { days }\end{array}$ & Alive, day 418 \\
\hline 11 & 69 & M & $\begin{array}{l}\text { MM-IgG } \\
\text { kappa }\end{array}$ & 2009 & +13 & Colon & +15 & 4 & Steroids & $\begin{array}{l}\mathrm{CR} \text { at } \\
3 \text { days }\end{array}$ & Alive, day 375 \\
\hline 12 & 61 & M & $\begin{array}{l}\text { MM-IgG } \\
\text { lambda }\end{array}$ & 2009 & +11 & Colon & +16 & 4 & Steroids & NR & $\begin{array}{l}\text { Died, day } 21, \\
\text { sepsis }\end{array}$ \\
\hline 13 & 49 & $\mathrm{~F}$ & $\begin{array}{l}\text { MM-IgG } \\
\text { kappa }\end{array}$ & 2009 & +12 & Colon & +27 & 2 & Steroids & $\begin{array}{l}\text { CR at } \\
15 \text { days }\end{array}$ & Alive, day 335 \\
\hline 14 & 51 & M & $\begin{array}{l}\text { MM-IgA } \\
\text { kappa }\end{array}$ & 2009 & +10 & Colon & +15 & 3 & Steroids & $\begin{array}{l}\text { CR at } \\
2 \text { days }\end{array}$ & Alive, day 221 \\
\hline 15 & 65 & $\mathrm{~F}$ & $\begin{array}{l}\text { MM- } \\
\text { lamdba }\end{array}$ & 2009 & +10 & Colon & +14 & 3 & Steroids & $\begin{array}{l}\mathrm{CR} \text { at } \\
3 \text { days }\end{array}$ & Alive, day 213 \\
\hline 16 & 59 & $\mathrm{~F}$ & $\begin{array}{l}\text { MM-IgG } \\
\text { lambda }\end{array}$ & $2009^{d}$ & +10 & Colon & +14 & 4 & $\begin{array}{l}\text { Steroids, infliximab; } \\
\text { budesonide, } \\
\text { cholestyramine }\end{array}$ & PR & Alive, day 165 \\
\hline 17 & 43 & $\mathrm{~F}$ & AITL & 2009 & +11 & Colon & +16 & 3 & Steroids & $\begin{array}{l}\mathrm{CR} \text { at } \\
2 \text { days }\end{array}$ & Alive, day 117 \\
\hline
\end{tabular}

Abbreviations: AITL, angioimmunoblastic T-cell lymphoma; CR, complete response to therapy (resolution of symptoms); DLBCL, diffuse large B-cell lymphoma; F, female; M, male; MM, multiple myeloma; NR, no response to therapy; PR, partial response (improvement in symptoms, or resolution of symptoms, but still receiving immune suppressive therapy).

${ }^{\mathrm{a}}$ The day of engraftment was defined as the first of three consecutive days that the absolute neutophil count was $\geq 500 \mu$ l.

${ }^{\mathrm{b}}$ Number of days following autologous transplant.

${ }^{\mathrm{C}}$ Time following initiation of therapy.

${ }^{\mathrm{d}}$ Second progenitor cell transplant.

\section{Clinical Findings}

Of all autologous transplants at our institution during the study period, multiple myeloma patients represented $66 \%(254 / 388)$ within the 6-year time interval. Patients with non-Hodgkin's lymphoma represented 15\% (59/388). These two entities were the most frequent diagnostic reasons for undergoing autologous transplant. Hodgkin's lymphoma (9\%), amyloidosis (4\%), and acute myeloid leukemia (2\%) were the next most frequent reasons for transplant.

The patient series was comprised of 10 men and 7 women. Ages ranged from 30 to 70 (average age: 54.8) years. Despite the large number of patients transplanted for other reasons, 15 patients had a history of multiple myeloma. One had a history of primary mediastinal diffuse large B-cell lymphoma and one had angioimmunoblastic T-cell lymphoma.
In those undergoing transplantation for multiple myeloma, four patients (patients 1, 2, 4, and 16) were receiving their second hematopoietic stem cell transplant. No predominant paraprotein type or recurring cytogenetic abnormality was present.

In all patients, the time of engraftment ranged from 9-14 (mean 11.5) days and was defined as the first of three consecutive days that the absolute neutrophil count was $\geq 500$ per $\mu$ l. Clinically, graftversus-host disease ranged from exclusively lower gastrointestinal tract involvement to involvement of extracolonic sites, such as the skin, liver, and upper gastrointestinal tract.

On the basis of the total number of autologous transplants carried out at our institution over the 6 -year study period, the total incidence rate of autologous graft-versus-host disease was 4\% (17/388 patients). Of multiple myeloma patients undergoing 
autologous transplantation, the incidence was 6\% (15/254 patients), and among patients undergoing autologous transplant for non-Hodgkin's lymphoma, the incidence was 3\% (2/59 patients).

\section{Pathological Findings}

Biopsies were performed from 13 to 195 days following stem cell transplant after myeloablation (median 15 days). All 16 colonic biopsies showed pathological evidence for graft-versus-host disease using the aforementioned accepted criteria for allogeneic graft-versus-host disease. Two patients had pathological changes equivalent to grade 1 graftversus-host disease, five had grade 2 graft-versushost disease, five had grade 3 graft-versus-host disease, and five had grade 4 graft-versus-host disease. Corresponding to the varied grades, there was a wide spectrum of histological findings, ranging from few apoptotic crypt epithelial cells to complete denudation of the epithelium and extensive crypt dropout (Figures 1a-d). One case (patient 15) had pathological changes not emphasized or commonly reported in graft-versus-host disease: dilated damaged crypts without crypt abscesses (Figure 1e) and mucosal hemorrhage with hemosiderin deposition (Figure 1f). On the basis of the histopathological features, clinical presentation, and dramatic clinical improvement with steroids, these cases were interpreted clinically and pathologically as autologous graft-versus-host disease.

Histopathological changes of graft-versus-host disease were also seen in biopsies from extracolonic sites of early patients in our series. Three patients had skin biopsies showing interface dermatitis and epidermal necrosis consistent with cutaneous graftversus-host disease (Figure 2a). Four cases showed concurrent small intestinal changes consistent with graft-versus-host disease (Figure 2b). Finally, one case (patient 1) had primarily skin involvement with subsequent liver involvement and lacked gastrointestinal symptoms. One liver biopsy on day 199 showed lymphocytic and neutrophilic portal triaditis, and late in his clinical course, a second biopsy showed regenerative changes and portal infiltration with progressive periportal fibrosis, suggestive of recurrent graft-versus-host disease.

Follow-up colonic biopsies in early patients with a partial response or no response yielded either similar or partially attenuated pathological findings in comparison with the initial biopsies. No followup biopsies were pursued in patients with complete therapeutic responses.

\section{Treatment}

Responses to steroid and immunosuppressive therapy were variable: outcomes ranged from a complete resolution of symptoms to death secondary to complications of the immunosuppressive treatment.
There were seven deaths-three from therapyrelated immunosuppression for autologous graftversus-host disease. The remaining four deaths followed relapse of primary disease (three patients) or peritransplant complications (one patient). In two patients who died within 100 days following the diagnostic biopsy, death followed biopsies showing grade 4 graft-versus-host disease. Of note, however, two cases that demonstrated grade 4/4 pathology (patients 11 and 16) and one case with a severe clinical presentation requiring hemicolectomy (patient 10) showed complete responses to steroid treatment and favorable outcomes.

Earlier patients in our series tended to have poorer outcomes, whereas treatment responses improved with earlier initiation of treatment in later patients. In the latter group, complete responses usually occurred within $24-72 \mathrm{~h}$. A small subset of recent patients did not respond in this manner (patients 7 , 12, and 16).

\section{Discussion}

In this study, we evaluated the clinical and pathological features of severe gastrointestinal graft-versus-host disease occurring in patients following autologous hematopoietic stem cell transplantation, a population that is theoretically exempt from this complication.

Acutely, graft-versus-host disease is a primary consideration as a cause of diarrhea in allogeneic transplant recipients, based on its high incidence, morbidity and mortality, and response to immunosuppressive treatment with steroid-based regimens. Autologous graft-versus-host disease has been described in up to $10 \%$ of patients after autologous hematopoietic stem cell transplantation and is typically manifested by a rash that responds to steroids. ${ }^{6,8}$ The incidence of gastrointestinal involvement ranges from 4 to $16 \%$, with higher incidences reported recently due to increased awareness of the syndrome. ${ }^{8}$ A recent review of 681 consecutive patients reported a $13 \%$ incidence rate of autologous graft-versus-host disease when specifically targeting the gastrointestinal tract but symptoms were typically classified as mild. ${ }^{6}$

Engraftment syndrome is clinically similar to graft-versus-host disease: defined by the presence of a fever, erythrodermatous rash, and non-cardiogenic pulmonary edema, typically within 4 days of engraftment. ${ }^{18,19}$ Comprehensive reviews on this syndrome have been published. ${ }^{20}$ It is believed to be caused by cytokine release and reports suggest that it is self-limited and, like autologous graftversus-host disease, rapidly reversed by early steroid therapy. Severe diarrhea, however, is not a typical finding in engraftment syndrome.

In our case series, we describe autologous hematopoietic stem cell recipients with severe diarrhea. Diarrhea in patients following hematopoietic stem 

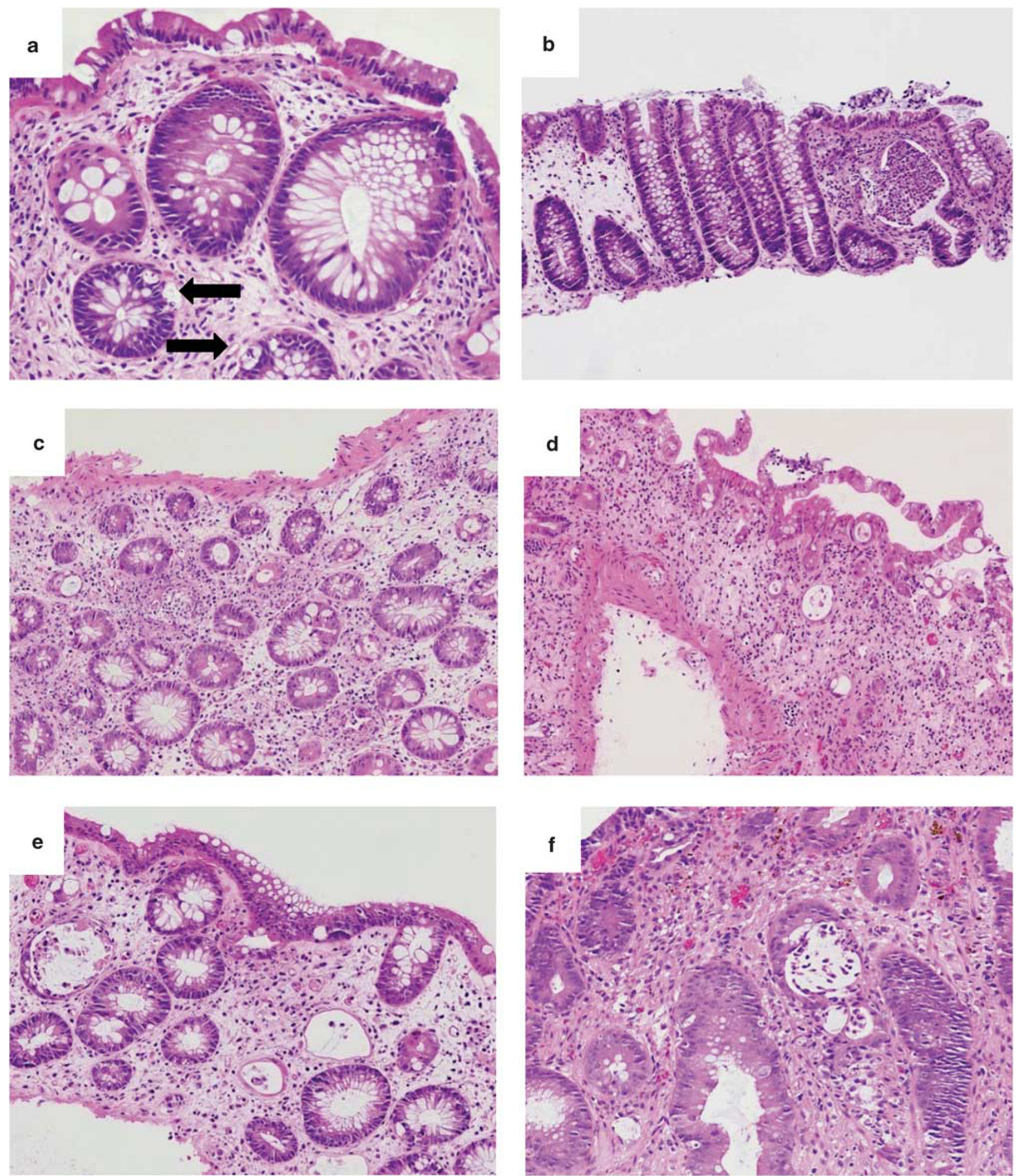

Figure 1 Features of colonic injury related to autologous graft-versus-host disease. Grade 1 with isolated crypt apoptoses (a), grade 2 with crypt abscess and rupture with crypt loss (b), grade 3 with contiguous area of crypt loss (c), and grade 4 with extensive crypt dropout and re-epithelialization (d). In case 15, unusual histological findings included dilated damaged crypts and mucosal hemorrhage with hemosiderin deposition (e, f).

cell transplantation is often worrisome and has a broad differential diagnosis clinically, including autologous graft-versus-host disease. Infections and drug effects are of particular importance and significance, as they mimic the pathological changes found in graft-versus-host disease (Table 2). 

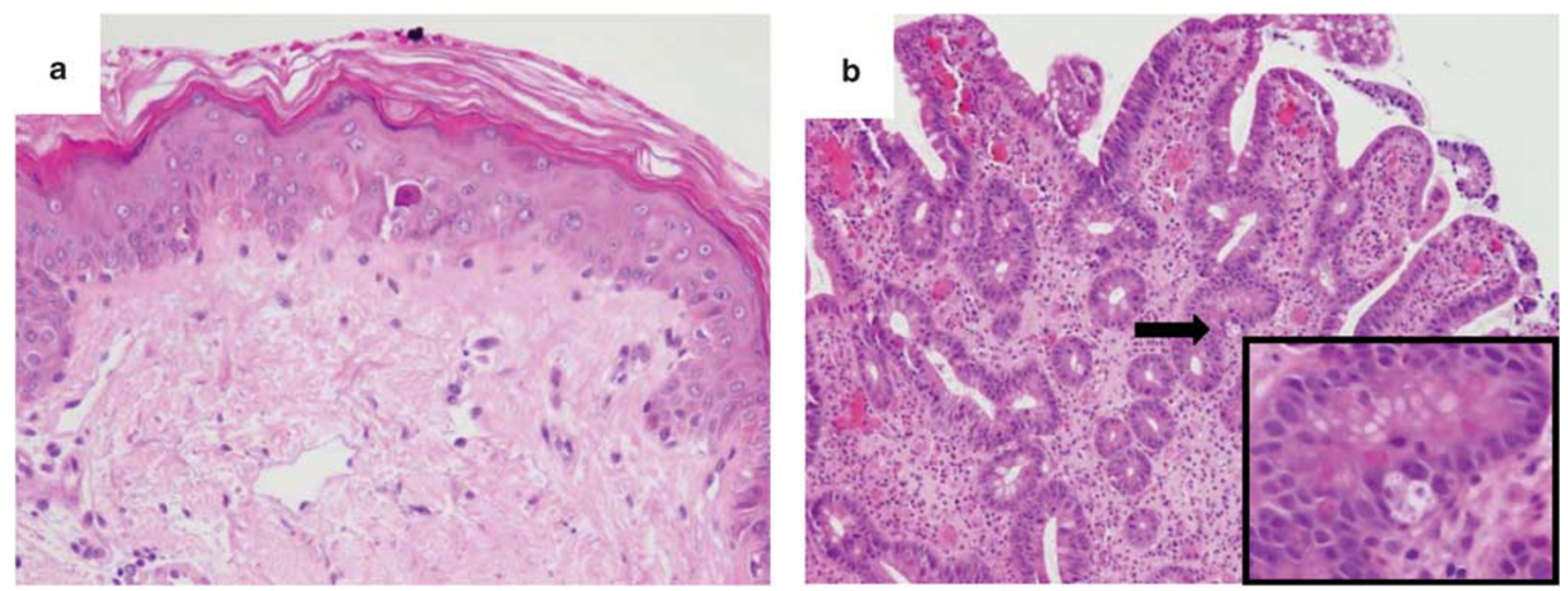

Figure 2 Autologous graft-versus-host disease in extracolonic sites. Representative biopsies of the skin from case 4 (a) and duodenum in case 9 (b) show focal epidermal necrosis (dyskeratotic keratinocyte) with subtle interface dermatitis and multiple isolated apoptotic epithelial cells, respectively, consistent with mild (grade 1) autologous graft-versus-host disease.

Table 2 Differential diagnosis of gastrointestinal graft-versushost disease-like pathology

\section{Infections}

Viral: cytomegalovirus, herpes simplex, adenovirus, enteroviruses

Medication related

Chemotherapy-related cytotoxicity

Immunosuppressive agents (mycophenolate formulations, cyclosporine, tacrolimus)

Non-steroidal inflammatory drugs

Laxatives

Engraftment syndrome

Preexisting inflammatory bowel disease or celiac disease

Transfusion-associated graft-versus-host disease

In allogeneic transplant recipients, colonic biopsy has been the most sensitive modality for the diagnosis of acute graft-versus-host disease. ${ }^{21}$ Published criteria for pathological grading of graft-versushost disease are slightly varied, but modifications of a four-tier scale apply widely, from 1 (mild) to 4 (severe). ${ }^{1,2}$ These criteria are based on the original grading schemes and have not dramatically changed in three decades. For the surgical pathologist, however, many of the pathological features of acute graft-versus-host disease are nonspecific. In the colon, 'exploding crypt cells' and apoptoses at crypt bases are found and used for grading of graftversus-host disease but are not always pathological. In general, biopsies performed within 10-20 days of allogeneic chemotherapeutic conditioning regimens also show apoptotic epithelial cells and render a diagnosis of acute pathology difficult unless other pathological changes or clinical data are present. ${ }^{22}$

Biopsies of patients in our series commonly transpired within the first 20 days following myeloablation, when severe diarrhea started. Grading using standard criteria developed for graft-versushost disease following allogeneic transplantation is suboptimal at this early time point, but the severity of clinical symptoms in our cases warranted colonoscopic investigation. In addition, the pathological changes of biopsies showed a spectrum of findings not limited to apoptotic epithelial cells, commonly the only findings described in patients without significant symptomatology within the first 20 days following conditioning. ${ }^{22}$ More than half of the patients in our series $(9 / 17)$ had colonic pathology corresponding to grade 3 or 4 graft-versus-host disease, including crypt dropout and de-epithelialization, pathology that would not be attributable to subtle changes induced by the conditioning regimen. The recovery of peripheral cell counts in our patient population at least days before the onset of gastrointestinal symptoms also argues against direct myeloablative toxicity. Thus, it would be unlikely that effects related to myeloablation would account for the constellation of clinical and pathological features. If temporally associated, delayed effects of chemotherapy are clearly difficult to tease away from pathological changes induced by autologous graft-versus-host disease. As many patients in our case series had recently received chemotherapy and there are no specific pathological changes to differentiate these two entities, the clinical scenario and response to treatment was then used to dictate the ultimate diagnosis.

Other non-chemotherapeutic drug effects are also known to mimic graft-versus-host disease-like changes but require a compatible clinical history. In the setting of autologous or syngeneic (twinto-twin) hematopoietic stem cell transplantation, immunosuppressive drugs may induce graft-versushost disease-like pathology, such as mycophenolate mofetil. ${ }^{15}$ Characteristic shared findings with both allogeneic and autologous graft-versus-host disease include crypt cell apoptosis with crypt atrophy and dropout. Crypt distortion and regenerative changes, 
including dilated damaged crypts, are more typical of mycophenolate-related injury. However, these immunosuppressive agents are not used for prophylaxis of graft-versus-host disease in autologous stem cell recipients because there is no lack of genetic disparity that would induce an alloresponse. Drugs known to cause increased apoptosis, such as nonsteroidal anti-inflammatory drugs ${ }^{16}$ and laxatives, ${ }^{17}$ are also not used in the peritransplant period. Medications that are used include prophylactic antimicrobials and anti-emetics for nausea, which are not known to induce histological change mimicking graft-versus-host disease.

For the surgical pathologist, excluding potential etiologies in autologous stem cell recipients can be impossible without an adequate clinical history. Many possible infectious agents must be eliminated from routine laboratory and microbiological studies, including $C$. difficile and other common bacterial infections. Fortunately, pathological characteristics do not overlap with changes related to graft-versushost disease. Acute self-limited colitis and specific or characteristic features such as pseudomembranes and granulomas are not typical of graft-versus-host disease. On the other hand, viral infections such as cytomegalovirus can display a vast array of pathological changes, including those mimicking graftversus-host disease: apoptotic enterocytes and crypt atrophy/loss. Typical viral inclusions are occasionally absent or rare from routinely prepared sections. Owing to the spectrum of changes in viral infections, lack of sensitive microbiological studies, and the possibility of coexisting viral infection with graft-versus-host disease, we recommend immunohistochemistry or in situ hybridization for CMV in all biopsies showing pathology consistent with autologous graft-versus-host disease. This is our institutional practice whether allogeneic or autologous transplant biopsies are interpreted. Depending on the clinical index of suspicion and incidence, herpes simplex virus and adenovirus immunostaining should also be considered. Other more unusual infectious etiologies require consideration on a caseby-case basis, especially when other causes are more likely. As a case in point: in one example from our series, despite an exhaustive investigation for infectious agents (patient 2)-including multiple send-out tests and electron microscopy-no causative organism was identified.

Transfusion-associated graft-versus-host disease could also theoretically induce pathology identical to that seen in autologous graft-versus-host disease. However, our patient population universally received 2500 rad irradiated blood products in the peritransplant period. These doses should be sufficient to reduce any transfused lymphocytes that may be capable of inducing a graft-versus-host response. ${ }^{23}$ In addition, transfusion-associated graft-versus-host disease is typically accompanied by concurrent decreases in peripheral blood cell counts and marrow aplasia due to transfused lymphocytes targeting hematopoietic cells. In our patient series, cell counts recovered during engraftment before or concurrent with the development of graft-versus-host disease.

Upon excluding alternative causes for gastrointestinal pathology, perhaps the most convincing clinical evidence of immune-related gastrointestinal pathology, rather than infections or another etiology, is the early response to immunosuppressive therapy. Despite marked pathological changes in the biopsies associated with severe clinical symptoms from patients in our case series, there were dramatic responses to steroid and immunosuppressive regimens when initiated early, guided by the information provided by pathological examination. Patients described earliest in our series (patients 1-5) had more variable outcomes without prompt immunosuppressive therapy. Many patients not initially treated with steroids did not improve clinically. With our institutional experience, however, prompt early treatment has resulted in dramatically improved clinical outcomes.

Theories vary regarding the pathogenesis of autologous graft-versus-host disease, but center around the loss of tolerance to 'self' that develops in a disrupted immune system, which could have multiple causes. Previous chemotherapy may deleteriously alter the content of regulatory $\mathrm{T}$ cells in the stem cell graft. Perhaps endogenous cells that survive conditioning and assist in post-transplant maintenance of self-tolerance are affected. ${ }^{9}$ Microchimerism due to maternal cells transmitted during fetal development and persisting throughout adult life has also been postulated as a cause. ${ }^{8}$ That observed cases of autologous graft-versus-host disease have occurred in the last 6 years suggests a possible link between new therapeutics such as lenalidomide and bortezomib, which have emerged as part of standard pretransplant chemotherapy during the rapid evolution of myeloma treatment. Potentially they alter regulatory $\mathrm{T}$ cell content in graft recipients or otherwise explain autologous graft-versus-host disease.

To our knowledge, this represents the largest series of autologous graft-versus-host disease in hematopoietic stem cell transplantation recipients. Other recently published articles on this subject have not intimately examined pathological changes seen on diagnostic biopsies. ${ }^{6,10,11}$ Patients with multiple myeloma comprise a large population undergoing autologous transplants and made up the majority of our study population. Reasons for this are unknown. Our series did not suggest a predilection based on specific diagnostic features of these myeloma patients (immunoglobulin subtype, karyotype, etc). One might postulate that recently introduced chemotherapeutic regimens may predispose to development of graft-versus-host disease immunopathology, but the majority of myeloma patients are not known to experience complications of this type despite highly standardized therapy. 
The predominance of autologous graft-versus-host disease in myeloma patients certainly deserves some attention, however. Our institution has only recently seen the clinical presentations described in this study, potentially coinciding with the introduction of novel pretransplant regimens that have been introduced for multiple myeloma over the last decade, such as the proteasome inhibitor- and thalidomide/lenalidomide-based regimens. ${ }^{24}$ On the other hand, the occurrence of autologous graftversus-host disease in patients within our series who had non-Hodgkin's lymphoma suggests that the entity is not unique to multiple myeloma.

Some limitations do apply to our study. Normal changes following conditioning for autologous hematopoietic stem cell transplantation are not well documented, as these patients are not biopsied and few studies would be approved to examine histological changes in asymptomatic patients following stem cell transplant. Although nearly all cases showed identical pathology to that seen in allogeneic stem cell recipients, subtle histopathological differences-including dilated damaged crypts and mucosal hemorrhage-were observed in autologous graft-versus-host disease that are not described in the gastrointestinal pathology of allogeneic graftversus-host disease-accordingly, the standard grading scheme for allogeneic graft-versus-host disease may not apply to autologous graft-versus-host disease. The finding of dilated damaged crypts mimics a characteristic feature of mycophenolate-induced colitis even though this patient population does not require immunosuppression from such agents. However, these pathological differences were seen in just one case in our series-other microscopic findings were identical to allogeneic acute graftversus-host disease. Autologous graft-versus-host disease is conceptually and theoretically a distinct pathogenesis when contrasted to allogeneic graftversus-host disease, but routine histological examination may not be sensitive enough to identify pathological differences. Thus, it is uncertain whether the widely used grading scheme for graftversus-host disease will correlate with outcomes following immunosuppression for autologous graftversus-host disease. Future investigation will be required to determine whether tailored grading schemes would correlate better with clinical symptoms and outcomes and whether there is further overlap with histological features of drug-induced and/or infectious pathology.

In summary, autologous graft-versus-host disease has the potential to cause critical illness in the hematopoietic stem cell transplantation patient population. In our institutional population of autologous transplant recipients, $4 \%$ developed this complication $(6 \%$ among multiple myeloma patients) and had variable responses to steroids with or without supplemental immunosuppressive therapy. However, a significant proportion saw dramatic improvements and excellent outcomes after early therapeutic intervention. Pathologists should be aware of the importance of recognizing autologous graft-versus-host disease in gastrointestinal biopsies from autologous stem cell recipients in order to guide early therapy.

\section{Acknowledgements}

We thank Dr Jose Plaza for reviewing photomicrographs from skin biopsies. Special thanks to the administrative staff in the Surgical Pathology department and to the technical staff at Dynacare Laboratories for their expertise and willing support.

\section{Disclosure/conflict of interest}

The authors declare no conflict of interest.

\section{References}

1 Sale GE, Shulman HM, McDonald GB, et al. Gastrointestinal graft-versus-host disease in man. A clinicopathologic study of the rectal biopsy. Am J Surg Pathol 1979;3:291-299.

2 Lerner KG, Kao GF, Storb R, et al. Histopathology of graft-vs-host reaction (GvHR) in human recipients of marrow from HL-A-matched sibling donors. Transplant Proc 1974;6:367-371.

3 Socie G. Graft-versus-host disease-from the bench to the bedside? N Engl J Med 2005;353:1396-1397.

4 Ball LM, Egeler RM, EBMT Paediatric Working Party. Acute GvHD: pathogenesis and classification. Bone Marrow Transplant 2008;41(Suppl 2):S58-S64.

5 Ferrara JL, Levine JE, Reddy P, et al. Graft-versus-host disease. Lancet 2009;373:1550-1561.

6 Holmberg L, Kikuchi K, Gooley TA, et al. Gastrointestinal graft-versus-host disease in recipients of autologous hematopoietic stem cells: Incidence, risk factors, and outcome. Biol Blood Marrow Transplant 2006;12:226-234.

7 Socie G, Blazar BR. Acute graft-versus-host disease; from the bench to the bedside. Blood 2009;114:4327-4336.

8 Washington K, Jagasia M. Pathology of graft-versushost disease in the gastrointestinal tract. Hum Pathol 2009;40:909-917.

9 Drobyski WR, Hari P, Keever-Taylor C, et al. Severe autologous GVHD after hematopoietic progenitor cell transplantation for multiple myeloma. Bone Marrow Transplant 2009;43:169-177.

10 Kline J, van Besien K, Nathanson J, et al. Severe intestinal graft-versus-host disease following autologous stem cell transplantation. Bone Marrow Transplant 2006;38:391-392.

11 Goddard DS, Ruben BS, Mathes ED, et al. A case of severe cutaneous, GI and liver GVHD in a patient with multiple myeloma, status-post-second auto-SCT. Bone Marrow Transplant 2010;45:409-411.

12 Latif T, Pohlman B, Kalaycio M, et al. Syngeneic graftversus-host disease: a report of two cases and literature review. Bone Marrow Transplant 2003;32:535-539.

13 Spaner D, Lowsky R, Fyles G, et al. Acute intestinal graft-versus-host disease in a syngeneic bone marrow transplant recipient. Transplantation 1998;66:1251-1253. 
14 Hwang WY, Goh YT, Tan CH, et al. Severe acute graftversus-host disease occurring after syngeneic BMT for AML in a patient not given prior cyclosporin $\mathrm{A}$ therapy. Bone Marrow Transplant 2000;25:205-207.

15 Parfitt JR, Jayakumar S, Driman DK. Mycophenolate mofetil-related gastrointestinal mucosal injury: variable injury patterns, including graft-versus-host disease-like changes. Am J Surg Pathol 2008;32:1367-1372.

16 Lee FD. Importance of apoptosis in the histopathology of drug related lesions in the large intestine. J Clin Pathol 1993;46:118-122.

17 Walker NI, Bennett RE, Axelsen RA. Melanosis coli. A consequence of anthraquinone-induced apoptosis of colonic epithelial cells. Am J Pathol 1988;131:465-476.

18 Katzel JA, Mazumder A, Jagannath S, et al. Engraftment syndrome after hematopoietic stem cell transplantation in multiple myeloma. Clin Lymphoma Myeloma 2006;7:151.

19 Maiolino A, Biasoli I, Lima J, et al. Engraftment syndrome following autologous hematopoietic stem cell transplantation: definition of diagnostic criteria. Bone Marrow Transplant 2003;31:393-397.
20 Spitzer TR. Engraftment syndrome following hematopoietic stem cell transplantation. Bone Marrow Transplant 2001;27:893-898.

21 Ross WA, Ghosh S, Dekovich AA, et al. Endoscopic biopsy diagnosis of acute gastrointestinal graft-versushost disease: rectosigmoid biopsies are more sensitive than upper gastrointestinal biopsies. Am J Gastroenterol 2008;103:982-989.

22 Epstein RJ, McDonald GB, Sale GE, et al. The diagnostic accuracy of the rectal biopsy in acute graft-versus-host disease: A prospective study of thirteen patients. Gastroenterology 1980;78:764-771.

23 Drobyski W, Thibodeau S, Truitt RL, et al. Third-partymediated graft rejection and graft-versus-host disease after T-cell-depleted bone marrow transplantation, as demonstrated by hypervariable DNA probes and HLA-DR polymorphism. Blood 1989;74:2285-2294.

24 Anderson KC, Alsina M, Bensinger W, National Comprehensive Cancer Network (NCCN), et al. Multiple myeloma. Clinical practice guidelines in oncology. J Natl Compr Canc Netw 2007;5:118-147. 